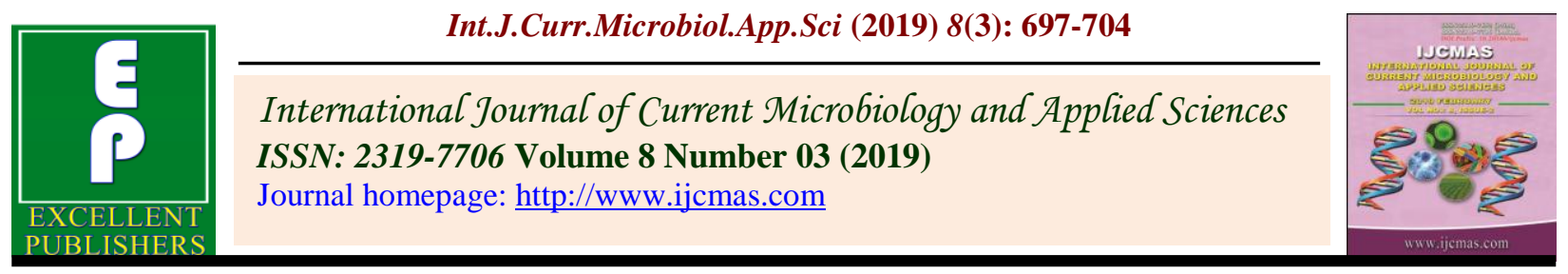

\title{
Effect of Soil Texture on Drying Pattern of Soil Moisture after Saturation
}

\author{
Pragyan Paramita Rout* and K. Arulmozhiselvan \\ Department of Soil Science and Agricultural Chemistry, Tamil Nadu Agricultural University \\ (TNAU), Coimbatore-641003, Tamil Nadu, India \\ *Corresponding author
}

\section{Keywords}

Soil texture,

Gravimetric water content, Moisture depletion rate, Drying pattern

Article Info

Accepted:

07 February 2019

Available Online:

10 March 2019

\section{A B S T R A C T}

The variability in water retention in soil is primarily attributable to soil texture which is mainly responsible for pore geometry and discontinuity, when compared to soil mineralogy. Under field conditions soil moisture variability is a major constraint for proper soil water management. In the present study, a pot experiment was conducted with an objective of assessing the effect of soil texture on moisture content and its depletion rate. For this purpose, the soils of seven variable textures were pre saturated and allowed to follow a drying period up to 15 days. The absolute moisture content of the soil was measured by direct gravimetric method. Besides, per cent moisture saturation and moisture depletion rate were also computed. The results showed that sandy texture (sandy, loamy sand) had low gravimetric water content (GWC) followed by a moderate GWC in loamy texture (sandy clay loam, clay loam, sandy loam). The highest GWC was recorded in clay texture (clay and sandy clay). The sandy texture exhibited a sharp drop in GWC up to a period of 7 days and thereafter attained a steady state of depletion. The results clearly indicated that fine clayey texture exhibited initially low depletion rate of 2.28 per cent GWC loss/day and could retain moisture for long period, wherein coarse sandy texture lost moisture at a faster rate with an initial depletion rate of 6.70 per cent GWC loss/day. The study concluded that there was a significant variability in moisture content and moisture retention pattern among the soils of variable texture. Hence, such in situ variability in drying pattern must be assessed prior to irrigation for efficient water management.

\section{Introduction}

Soil is highly heterogeneous, with soil moisture being one of its most important spatiotemporal variables (Parvin and Degre, 2016). Soil moisture (water) is an inevitable part of three phase system of soil which comprises of solids (minerals), air and water (Das, 2004; Craig, 2005). The moisture dynamics of soil affect water fluxes throughout the soil profile, evapotranspiration and surface erosion (Mittelbach et al., 2012), hence has significant influence on engineering (Terzaghi, 1943), agronomic (Haines, 1923; Baver, 1956), geological (Fang and Daniels, 2006), ecological and hydrological (Hillel, 1980) behavior of soil. Mechanical properties of soil viz., consistency, compatibility, cracking, swelling, shrinkage and density are also dependent on soil moisture content (Jones, 1990). Furthermore, it has a major role in plant growth, sustenance of natural 
ecosystems and biodiversity in soil (Howell, 2001).

The moisture retention relationships, characterized by soil water content and potential are not unique and are affected by several environmental and soil factors (Teuling and Troch, 2005).The variability in soil texture which is responsible for irregular pore geometry and discontinuity, are the primary soil properties that influences soil water retention (Fares et al., 2011). In agricultural fields, the particle size distribution in soil is non-uniform. In different locations, the soils have variable texture and hence have different pore volume and clay content, accordingly exhibit variations in moisture content under same environment(Dobriyal et al., 2012). Hence, the accurate quantification and detailed investigation on moisture content as well as its retention properties in various soil textures has practical implications in hydrological studies, irrigation scheduling, validation of soil water models and other environmental assessments (SushaLekshmi et al., 2014).

With this background, a pot experiment was conducted with an aim of assessing the effect of soil texture on moisture content, moisture depletion during drying period after saturation.

\section{Materials and Methods}

\section{Experimental design and treatment details}

A pot experiment was conducted in soils of seven variable texture with three replications. In this experiment, the soil samples were presaturated with water and allowed to dry up to a period of 15 days. The absolute moisture content of the soil was measured by direct gravimetric method thrice a day from saturation to drying. The experimental design and treatment details are presented in Table 1.

\section{Collection of soils of variable texture and} preliminary analysis

The composite surface $(0-15 \mathrm{~cm})$ soil samples were collected from different locations of Tamil Nadu having majorly occurring seven texture viz., sandy, sandy loam, sandy clay loam, loamy sand, clay loam, sandy clay and clay. The textural analysis was carried out using International pipette method (Piper, 1966). Other physical properties viz., bulk density (BD), porosity and water holding capacity (WHC) were estimated by using Keen Rackzowski box (Hillgard apparatus) method. The moisture at field capacity (FC) and permanent wilting point (PWP) of soil moisture tension in these soils was estimated using pressure plate apparatus by following North Carolina State University Substrate Laboratory (NCSL) method as described by Milks et al., (1989).

\section{Methodology of experimentation}

For the experimental set up, soils of seven variable texture were collected, processed to pass through $2 \mathrm{~mm}$ sieve, and then filled in plastic pots of $10 \mathrm{~kg}$ capacity in three replications. In each pot $8 \mathrm{~kg}$ of dry soil was filled. While starting the experiment, initially, on previous day evening, distilled water was added to each pot through the sides in order to saturate the soil and permit air to escape from the center. After complete saturation with ponding of water on surface the pot was left aside.

Then the soil was allowed to drain the excess water through the hole provided at the bottom of the pot. Thereafter, the pot was left overnight to uniformly moisten the soil throughout. The pre-saturated soil was allowed to dry and then soil moisture was recorded thrice a day. For this purpose, the entire pot was weighed on a digital weighing balance. The weight of the pot along with soil 
was measured. The gravimetric water content was measured using the following formula

\begin{tabular}{lll} 
& \multicolumn{2}{l}{$\begin{array}{l}\text { Weight of pot with } \\
\text { moist soil }(\mathrm{g})-\end{array}$} \\
water & $\begin{array}{l}\text { Weight of pot with } \mathrm{X} \\
\text { content }(\%)\end{array}$ & $\frac{\text { dry soil }(\mathrm{g})}{\text { Weight of dry soil }}$ \\
& filled in pot $(\mathrm{g})$
\end{tabular}

For further interpretation, the soil moisture was also expressed in terms of volumetric moisture content using the following formula

\section{Moisture depletion rate}

The moisture depletion rate on per day basis (\% GWC loss/day) over a period of 15 days is calculated as follows

$\begin{aligned} & \text { Moisture } \\ & \text { depletion } \\ & \text { rate } \\ & (\%\end{aligned}$
$\begin{aligned} & \text { GWC } \\ & \text { loss }\end{aligned} \quad \begin{aligned} & \text { GWC (\%) at a particular day } \\ & \text { observation }\end{aligned}$
$\begin{aligned} & \text { No. of days at next } \\ & \text { /day })\end{aligned}$

Volumetric Gravimetric water content (gftatisticaltapalysisy of soil

water content $=\frac{\left(\mathrm{Mg} / \mathrm{m}^{3}\right)}{\text { Density of water }\left(\mathrm{Mg} / \mathrm{m}^{3}\right)}$

Estimation of moisture depletion rate in soils of variable texture during drying period

The gravimetric water content (\% GWC) in soils of seven variable textures was recorded for period of 15 days during drying period. In continuation, the moisture depletion rate (\% GWC loss/day) and per cent moisture saturation (\%) were also calculated on day basis using following formula

\section{Per cent moisture saturation}

The gravimetric water content at day 1 was taken as saturation and expressed as 100 per cent moisture. Thereafter, the percentage of moisture was calculated as per cent saturation on per day basis over a period of 15 days as follows

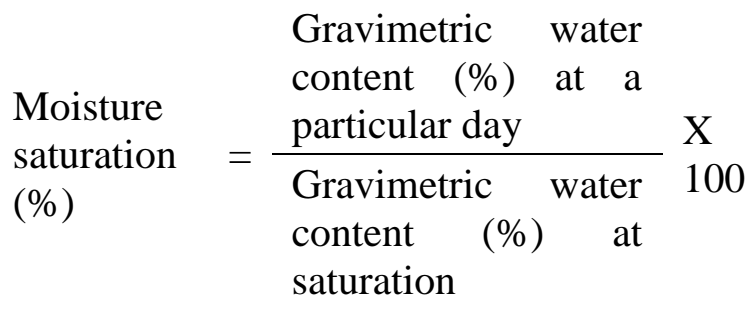

The data on gravimetrie- X 100 content recorded on day basis in soils of variable texture during drying period were subjected to analysis of variance (ANOVA) as suggested by Panse and Sukhatme (1985). The standard error of difference $\left(\mathrm{SE}_{\mathrm{d}}\right)$ and $\mathrm{CD}(\mathrm{P}=0.05)$ values were computed and used to test the significance of soil texture on gravimetric water content. For statistical analysis of data, Microsoft Excel (Microsoft Corporation, USA) package was used.

\section{Results and Discussion}

\section{Physical properties of soils}

The results on physical properties of soils (Table 2) showed that the soil of variable texture varied widely in their properties. The particle size analysis showed that sand fraction ranged from $17.6\left(\mathrm{~S}_{7}\right)$ to 91.2 per cent $\left(\mathrm{S}_{1}\right)$, silt fraction ranged from $4.3\left(\mathrm{~S}_{1}\right)$ to 26.1 per cent $\left(\mathrm{S}_{5}\right)$ and clay fraction ranged from $4.5\left(\mathrm{~S}_{1}\right)$ to 62.0 per cent $\left(\mathrm{S}_{7}\right)$. Among the samples, $S_{1}$ and $S_{2}$ were categorized as sandy; $\mathrm{S}_{3}, \mathrm{~S}_{4}$ and $\mathrm{S}_{5}$ were grouped as loamy; and $\mathrm{S}_{6}$ and $S_{7}$ were grouped as clayey in behavior.

The bulk density of soil samples ranged from $1.24 \mathrm{Mg} / \mathrm{m}^{3}$ in clay texture to $1.69 \mathrm{Mg} / \mathrm{m}^{3}$ in 
sandy texture. The clay texture had the highest porosity of 53.3 per cent and sandy texture recorded the lowest porosity of 36.4 per cent. The field capacity (FC) and permanent wilting point (PWP) varied among the samples. The sandy texture recorded the lowest FC and PWP of 13.9and 8.1 per cent VWC, wherein clay texture recorded the highest FC and PWP of 47.8and 34.6 per cent VWC respectively. The available water capacity of soil samples ranged from 5.8 to 18.9 per cent VWC.

Depletion of soil moisture in soils of variable texture during drying period

The gravimetric water content (\% GWC) in soils of seven variable texture was recorded for period of 15 days during drying period. The soil texture has a profound influence on GWC. The effect of texture on depletion of soil moisture was compared statistically.

\section{Gravimetric water content}

The results on effect of soil texture on GWC over a period of 15 days (Fig. 1) showed that the lowest GWC of 19.47 per cent was recorded in sandy texture and the highest GWC of 36.43 per cent was observed in clayey texture at saturation on day 1 with an overall mean of 30.12 per cent GWC. This might be due to the high micro pores in clayey texture that could hold more water even after draining of free gravitational water after saturation (Qi et al., 2018). Similar results were also reported by Payero et al., (2017).

In sandy and loamy sand texture, 50 per cent GWC was attained in day 3. However in other texture, 50 per cent GWC was recorded in day 9 except sandy clay texture which have recorded 50 per cent GWC in day 8. The GWC ranged from 0.31 per cent in sandy texture to 6.77 per cent in clayey texture on day 15 with overall mean of 3.00 per cent GWC. The textural mean ranged from 5.74 per cent GWC in sandy texture to 22.56 per cent GWC in clayey texture. The results clearly indicated that clayey texture could retain moisture for long period wherein sandy texture drained water in a faster rate. This might be attributed to the fact that clayey texture with fine soil particles have significant fraction of water that might be held tightly to clay matrix by strong matric forces which is responsible for high water retention capacity (Easton, 2016).

The change in GWC followed almost a linear decreasing trend as drying period proceeded in all texture. However, rate of decrease was steady in fine clayey texture (clay, sandy clay), loamy texture (sandy clay loam, clay loam, sandy loam). In coarse sandy texture (sandy and loamy sand), there was a sudden drop in water content during the initial period of 7 days and thereafter it followed a steady depletion trend. Such phenomenon might have occurred due to the initial draining of water from macro pores at a faster rate in coarse textured soil and thereafter the water in micro pore get emptied comparatively at a slower rate (Morgan et al., 2001).

Among soil texture, sandy and loamy sand texture had similar effect on gravimetric water content and were statistically at par with a mean value of 5.74 and 6.67 per cent GWC respectively. Other texture viz., sandy clay loam, sandy loam and clay loam had similar water content with a mean value of 19.42, 19.28 and 20.23 per cent GWC respectively.

The clay texture recorded higher water content $(22.56 \%$ GWC) than other texture which was statistically significant. Similar water retention behavior in soils of variable texture was also reported by Huang and Bingke (2016). 


\section{Per cent moisture saturation}

The results on effect on soil texture on per cent moisture saturation (Table 3) showed that the moisture saturation progressively decreased as drying period progressed. At day 1 , all soil texture attained 100 per cent moisture saturation. On day 2, the lowest moisture saturation of 65.61 per cent was recorded in sandy texture and the highest moisture saturation of 93.75 per cent was observed in clayey texture with an overall mean of 85.36 per cent. In sandy and loamy sand texture, 50 per cent moisture saturation was achieved in day 2. However in other texture, 50 per cent moisture saturation was recorded in day 9 except sandy clay texture that recorded 50 per cent moisture saturation in day 8. At day 15, per cent moisture saturation was lowest in loamy sand texture $(1.45 \%)$ and highest in clay texture $(18.58 \%)$ with an overall mean of 8.88 per cent. The textural mean of moisture saturation ranged from 29.46 to61.92 per cent. Similar results were also reported by Amooh and Bonsu (2015) who stated that the sandy loam texture had more moisture saturation than coarse textured soil (loamy sand and sand).

Table.1 Treatment details of pot experiment in soils of variable texture

\begin{tabular}{|c|l|l|l|}
\hline Tr. No. & \multicolumn{2}{|l|}{ Soil types (7 texture) } & with location \\
\hline $\mathbf{T}_{\mathbf{1}}$ & Sandy & $:$ & Ervadi, Nagapattinam $\left(10.765^{\circ} \mathrm{N}, 79.842^{\circ} \mathrm{E}\right)$ \\
\hline $\mathbf{T}_{\mathbf{2}}$ & Loamy sand & $:$ & Andipatti,Theni $\left(10.002^{\circ} \mathrm{N}, 77.616^{\circ} \mathrm{E}\right)$ \\
\hline $\mathbf{T}_{\mathbf{3}}$ & Sandy clay loam & $:$ & LTFE, TNAU, Coimbatore $\left(11.015^{\circ} \mathrm{N}, 76.932^{\circ} \mathrm{E}\right)$ \\
\hline $\mathbf{T}_{\mathbf{4}}$ & Sandy loam & $:$ & Ayalur, Gobichettipalayam $\left(11.450^{\circ} \mathrm{N}, 77.430^{\circ} \mathrm{E}\right)$ \\
\hline $\mathbf{T}_{\mathbf{5}}$ & Clay loam & $:$ & Eachankudi, Thanjavur $\left(10.787^{\circ} \mathrm{N}, 79.138^{\circ} \mathrm{E}\right)$ \\
\hline $\mathbf{T}_{\mathbf{6}}$ & Sandy clay & $:$ & Ichipalayam, Erode $\left(11.341^{\circ} \mathrm{N}, 77.717^{\circ} \mathrm{E}\right)$ \\
\hline $\mathbf{T}_{\mathbf{7}}$ & Clay & $:$ & Wetland, TNAU, Coimbatore $\left(11.01^{\circ} \mathrm{N}, 76.93^{\circ} \mathrm{E}\right)$ \\
\hline Replication & $:$ & Three \\
\hline Design & $:$ & Completely Randomized Design $(\mathrm{CRD})$ \\
\hline Moisture & measurement & $:$ & Saturation to dry (Thrice a day) \\
\hline Duration & $:$ & 15 days \\
\hline
\end{tabular}

Table.2 Physical properties of soils of variable texture

\begin{tabular}{|c|c|c|c|c|c|c|c|c|c|}
\hline $\begin{array}{l}\text { S. } \\
\text { No. }\end{array}$ & $\begin{array}{c}\text { Soils of } \\
\text { variable } \\
\text { Texture }\end{array}$ & $\begin{array}{c}\text { Sand } \\
(\%)\end{array}$ & $\begin{array}{l}\text { Silt } \\
(\%)\end{array}$ & $\begin{array}{l}\text { Clay } \\
(\%)\end{array}$ & $\begin{array}{c}\text { Bulk } \\
\text { Density } \\
\left(\mathrm{Mg} / \mathrm{m}^{3}\right)\end{array}$ & $\begin{array}{c}\text { Porosity } \\
(\%)\end{array}$ & $\begin{array}{c}\text { Field } \\
\text { Capacity } \\
(\% \text { VWC })\end{array}$ & $\begin{array}{c}\text { Permanent } \\
\text { Wilting } \\
\text { Point } \\
\text { (\% VWC) }\end{array}$ & $\begin{array}{c}\text { Available } \\
\text { Water } \\
\text { Capacity } \\
\text { (\%VWC) }\end{array}$ \\
\hline $\mathbf{S}_{1}$ & Sandy & 91.2 & 4.3 & 4.5 & 1.69 & 36.4 & 13.9 & 8.1 & 5.8 \\
\hline $\mathbf{S}_{2}$ & Loamy sand & 82.5 & 8.3 & 9.2 & 1.61 & 39.3 & 14.9 & 8.4 & 6.5 \\
\hline $\mathbf{S}_{\mathbf{3}}$ & $\begin{array}{l}\text { Sandy clay } \\
\text { loam }\end{array}$ & 65.3 & 13.1 & 21.6 & 1.45 & 45.2 & 33.5 & 17.8 & 15.7 \\
\hline $\mathbf{S}_{4}$ & Sandy loam & 71.4 & 11.5 & 17.1 & 1.53 & 42.1 & 32.4 & 16.4 & 16.0 \\
\hline $\mathbf{S}_{5}$ & Clay loam & 42.3 & 26.1 & 31.6 & 1.42 & 44.9 & 38.8 & 19.9 & 18.9 \\
\hline $\mathbf{S}_{6}$ & Sandy clay & 57.5 & 4.5 & 38.0 & 1.36 & 48.7 & 46.6 & 32.2 & 14.4 \\
\hline $\mathbf{S}_{7}$ & Clay & 17.6 & 20.4 & 62.0 & 1.24 & 53.3 & 47.8 & 34.6 & 13.2 \\
\hline
\end{tabular}

VWC: Volumetric Water Content (\%) 
Table.3 Effect of soil texture on Per cent moisture saturation (\%) during drying period

\begin{tabular}{|c|c|c|c|c|c|c|c|c|c|c|c|c|c|}
\hline Texture & Day 1 & $\begin{array}{c}\text { Day } \\
2\end{array}$ & $\begin{array}{c}\text { Day } \\
\mathbf{3}\end{array}$ & $\begin{array}{c}\text { Day } \\
4\end{array}$ & $\begin{array}{c}\text { Day } \\
6\end{array}$ & $\begin{array}{c}\text { Day } \\
7\end{array}$ & $\begin{array}{c}\text { Day } \\
8\end{array}$ & $\begin{array}{c}\text { Day } \\
9\end{array}$ & $\begin{array}{c}\text { Day } \\
10\end{array}$ & $\begin{array}{c}\text { Day } \\
13\end{array}$ & $\begin{array}{c}\text { Day } \\
14\end{array}$ & $\begin{array}{c}\text { Day } \\
15\end{array}$ & Mean \\
\hline $\mathbf{S}$ & 100.00 & 65.61 & 49.60 & 42.02 & 28.77 & 23.12 & 17.38 & 12.73 & 8.70 & 2.13 & 1.89 & 1.58 & 9.46 \\
\hline LS & 100.00 & 72.16 & 52.01 & 46.98 & 32.18 & 25.28 & 21.34 & 17.40 & 13.08 & 5.82 & 3.51 & 1.45 & 32.60 \\
\hline SCL & 100.00 & 92.76 & 86.26 & 79.62 & 72.10 & 61.59 & 55.28 & 48.65 & 40.85 & 30.35 & 20.22 & 11.43 & 58.26 \\
\hline SL & 0.0 & 90.50 & 83.22 & 79.57 & 71.95 & 6 & 5 & 4 & 47 & 28 & .85 & 9.52 & 57.97 \\
\hline CL & 100.00 & 91.21 & 85.16 & 80.23 & 67.67 & 62.74 & 56.62 & 50.36 & 45.45 & 32.15 & 22.61 & 12.16 & 58.86 \\
\hline SC & 100.00 & 91.51 & 82.35 & 74.15 & 64.43 & 58.22 & 52.46 & 45.39 & 38.73 & 25.15 & 17.07 & 7.47 & 54.74 \\
\hline C & 100.00 & 93.75 & 88.51 & 82.50 & 74.45 & 65.36 & 58.54 & 51.87 & 45.39 & 35.68 & 28.36 & 18.58 & 61.92 \\
\hline Mean & 100.00 & 85.36 & 75.30 & 69.30 & 58.79 & 51.41 & 45.25 & 39.56 & 33.67 & 22.94 & 16.07 & 8.88 & \\
\hline
\end{tabular}

Table.4 Effect of soil texture on Moisture depletion rate (\% GWC loss / day) during drying period

\begin{tabular}{|c|c|c|c|c|c|c|c|c|c|c|c|c|}
\hline Texture & Day & Day & Day & Day & Day & Day & Day 8 & Day & Day & Day 13 & Day & Mean \\
& $\mathbf{1}$ & $\mathbf{2}$ & $\mathbf{3}$ & $\mathbf{4}$ & $\mathbf{6}$ & $\mathbf{7}$ & & $\mathbf{9}$ & $\mathbf{1 0}$ & & \\
\hline S & 6.70 & 3.12 & 1.48 & 1.29 & 1.10 & 1.12 & 0.91 & 0.79 & 0.43 & 0.05 & 0.06 & $\mathbf{1 . 5 5}$ \\
\hline LS & 5.69 & 4.12 & 1.03 & 1.51 & 1.41 & 0.80 & 0.81 & 0.89 & 0.49 & 0.47 & 0.42 & $\mathbf{1 . 6 0}$ \\
\hline SCL & 2.41 & 2.17 & 2.21 & 1.25 & 3.51 & 2.10 & 2.21 & 2.60 & 1.17 & 3.38 & 2.93 & $\mathbf{2 . 3 6}$ \\
\hline SL & 3.16 & 2.42 & 1.21 & 1.27 & 2.78 & 2.80 & 1.54 & 2.35 & 1.57 & 3.47 & 3.10 & $\mathbf{2 . 3 3}$ \\
\hline CL & 3.02 & 2.08 & 1.69 & 2.16 & 1.70 & 2.10 & 2.15 & 1.69 & 1.52 & 3.28 & 3.59 & $\mathbf{2 . 2 7}$ \\
\hline SC & 2.84 & 3.07 & 2.75 & 1.63 & 2.08 & 1.93 & 2.36 & 2.23 & 1.52 & 2.70 & 3.22 & $\mathbf{2 . 3 9}$ \\
\hline C & 2.28 & 1.91 & 2.19 & 1.47 & 3.31 & 2.48 & 2.43 & 2.36 & 1.18 & 2.67 & 3.57 & $\mathbf{2 . 3 5}$ \\
\hline Mean & $\mathbf{3 . 7 3}$ & $\mathbf{2 . 7 0}$ & $\mathbf{1 . 7 9}$ & $\mathbf{1 . 5 1}$ & $\mathbf{2 . 2 7}$ & $\mathbf{1 . 9 1}$ & $\mathbf{1 . 7 7}$ & $\mathbf{1 . 8 4}$ & $\mathbf{1 . 1 3}$ & $\mathbf{2 . 2 9}$ & $\mathbf{2 . 4 1}$ & \\
\hline
\end{tabular}

Fig.1 Depletion of gravimetric water content in soils of variable texture during drying period

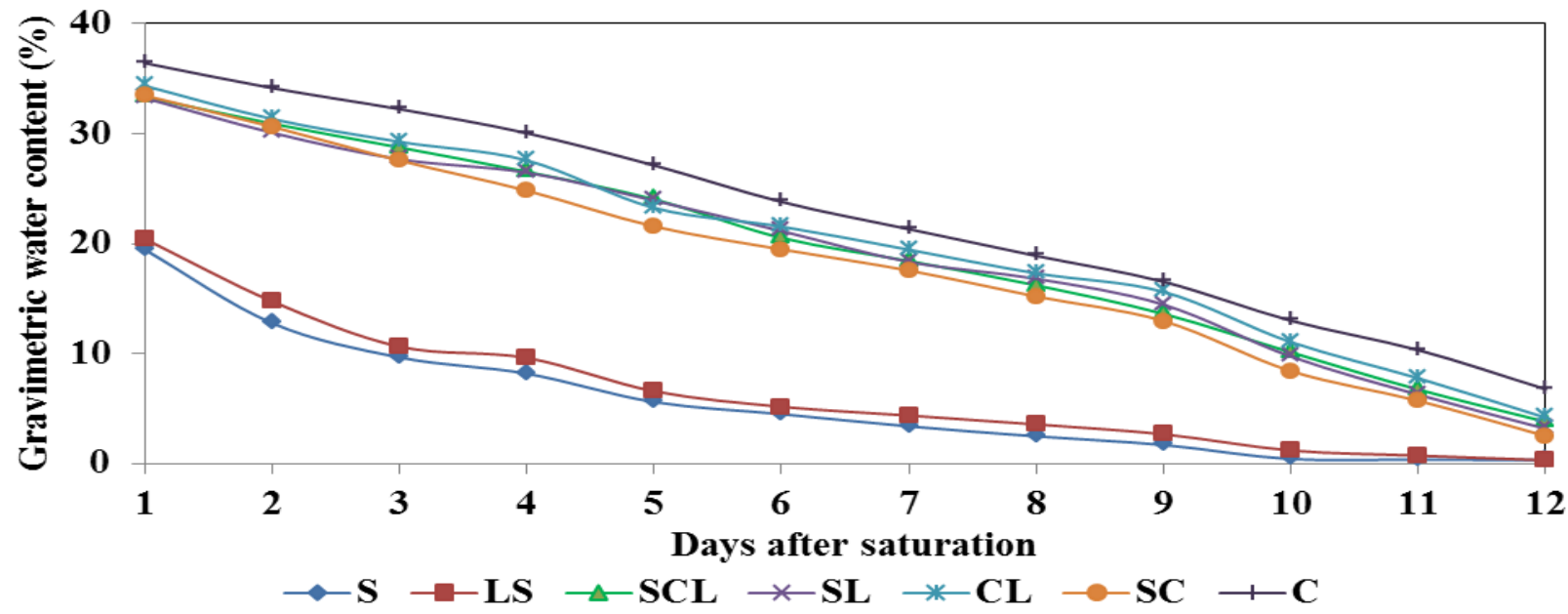




\section{Moisture depletion rate}

The results on effect of soil texture on moisture depletion rate (Table 4) showed that there was a significant variation in moisture depletion rate among the soil texture. On day 1 , the sandy texture recorded the highest moisture depletion rate of 6.70 per cent GWC loss/day and clay texture recorded the lowest moisture depletion rate of 2.28 per cent GWC loss/day with overall mean of 3.73 per cent GWC loss/day. The moisture depletion rate decreased as day proceeded over a period of 15 days in sandy and loamy sand texture. In other texture, the moisture depletion rate decreased followed by a subsequent increase at day 14 and ranged from 0.06 per cent in sandy texture to 3.59 per cent GWC loss/day in clay loam texture with over all mean of 2.41 per cent GWC loss/day. The textural mean of moisture depletion rate ranged from 1.55 to2.36 per cent GWC loss/day.

In conclusion, the present study showed that the soil texture significantly influenced the soil water content, moisture saturation and moisture depletion rate. Among seven soil texture, fine clayey texture (clay, sandy clay) recorded high water retention, prolonged period of moisture saturation as well as slow moisture depletion rate. The loamy texture (sandy clay loam, clay loam and sandy loam) had a moderate moisture saturation as well as depletion rate. The lowest water retention behavior was exhibited in coarse sandy texture (sandy and loamy sand) with a faster moisture depletion rate. The slope of decrease in gravimetric water content during drying period was steady in clayey and loamy texture, while it was sharp in sandy texture. Hence, proper assessment of moisture retention in soils of variable texture would help in identifying the extent of availability of soil water to crops and plan for proper scheduling of irrigation.

\section{References}

Amooh, M.K. and M. Bonsu. 2015. Effects of Soil Texture and Organic Matter on Evaporative Loss of Soil Moisture. Journal of Global Agriculture and Ecology.,3(3): 152-161.

Baver, L.D. 1956. Soil Physics, John Wiley and Sons, New York.

Craig, R.F. 2005.Craig's Soil Mechanics, E and FN Spon, London.

Das, B.M. 2004. Principles of Geotechnical Engineering, fifth ed., Thomson, Bangalore, India.

Dobriyal,P., A. Qureshi, R. Badola and S.A. Hussain. 2012. A review of the methods available for estimating soil moisture and its implications for water resource management. Journal of Hydrology.,458-459:110-117.

Easton, Z.M., 2016. Soil and Soil Water Relationships. Virginia Tech, Virginia State university. Publication BSE194P.

Fang, H.Y. and J.L. Daniels. 2006. Introductory geotechnical engineering - an environmental perspective, Taylor and Francis, New York.

Fares, A., F. Abbas and S. Fares. 2011. Field Calibrations of Soil Moisture Sensors in a Forested Watershed. Sensors., 11(6): 6354-6369.

Haines, W.B. 1923. The volume changes associated with variation of water content in soils. Journal of Agricultural Science., 13: 296-310.

Hillel. D. 1980. Fundamentals of soil physics, Academic press, New York.

Howell, T.A. 2001.Enhancing water use efficient in irrigated agriculture. Journal of Agronomy, 93(2): 281-289.

Huang, X. and G. Bingke. 2016. Review of soil moisture characteristic curve. Journal of Agricultural Technology Services., pp: 33.

Jones, H.G. 1990. Plant water relations and 
implications for irrigation scheduling, ActaHorticulturae, 278: 67-76.

Milks, R.R., W.C. Fonteno and R.A. Larson. 1989. Hydrology of horticultural substrates:Predicting physical properties of media in containers. Journal of American Society of Horticultural Science., 114: 53-56.

Mittelbach, H., I. Lehner and S.I. Seneviratne. 2012. Comparison of four soilmoisture sensor types under field conditions in Switzerland. Journal ofHydrology., 430-431: 39-49.

Morgan, K.T., L.R. Parsons and T.A. Wheaton. 2001. Comparison of laboratoryandfield-derived soil water retention curves for a fine sand soil using tensiometric, resistance and capacitance methods. Plant and Soil.,234: 153-157.

Panse, V.G. and P.V. Sukhatme. 1985. Statistical Methods for Agricultural Workers. Publication and information division. ICAR, New Delhi.

Parvin, N. and A. Degre. 2016. Soil-specific calibration of capacitance sensors considering clay content and bulk density. Soil Research.,54: 111-119.

Payero, J.O., X. Qiao, A. Khalilian, A.
Mirzakhani-Nafchi, R. Davis. 2017. Evaluating the Effect of Soil Texture on the Response of Three Types of Sensors Used to Monitor Soil Water Status. Journal of Water Resource and Protection., 9: 566-577.

Piper, C.S. 1966.Soil and plant analysis.International Science publishers Inc., New York.

Qi, Z., S. Jingfang and L. Wenwei. 2018. A survey about characteristics of soil water retention curve. 2nd International Workshop on Renewable Energy and Development (IWRED 2018), IOP Conference Series: Earth Environmental Science., 153: 062076.

SushaLekshmi, S.U., D.N. Singh and M.S. Baghini. 2014. A critical review of soil moisture measurement. Measurement.,54: 92-105.

Terzaghi, K. 1943.Theoretical Soil Mechanics, John Wiley and Sons, New York.

Teuling, A.J. and P.A. Troch. 2005. Improved understanding of soil moisturevariability dynamics. Geophysical Research Letters.,32: L05404.

\section{How to cite this article:}

PragyanParamita Rout and Arulmozhiselvan, K. 2019. Effect of Soil Texture on Drying Pattern of Soil Moisture after Saturation. Int.J.Curr.Microbiol.App.Sci. 8(03): 697-704. doi: https://doi.org/10.20546/ijcmas.2019.803.086 